\title{
World Culture, Educational Sociology and the Impact of Information \& Communication Technology on Teachers
}

\section{Gerald K. LeTendre}

Since the 1970s, educational sociology in Japan has been a fertile ground for theorizing about the role of culture in creating educational differences among nations. Japan, early on, was often posed by many as a test case of the universality of sociological theories, and my formal education included the study of classic works in English by Japanese (Amano, 1990; Ishida, 1993; Kariya, 1985; Nakane, 1970; Shimahara, 1978; 1979) as well as American (Cummings, 1983; Dore, 1965; Passin, 1965; Rohlen, 1983; Schoppa, 1991; Thurston, 1973) scholars. Interest in Japan's educational system was particularly intense in the 1980s and early 1990s (Stevenson \& Stigler, 1992; Vogel, 1979; White, 1987). Fanned by perceptions of Japan as a major economic competitor, studies of Japanese education were often used opportunistically in U.S. policy debates (LeTendre, 1999). Nonetheless, this created a unique window of opportunity for cross-disciplinary interaction and theorizing, as American scholars from diverse fields were drawn to the study of Japan.

My first foray into such a multi-disciplinary milieu occurred when my mentor, Tom Rohlen brought a diverse set of scholars to a conference on teaching and learning in Japan at the Green Gulch Zen Center near San Francisco in the early 1990s. The insights of these scholars on the nature of teaching and learning as it occurred in schools, companies, monasteries and the arts was published in Teaching and Learning in Japan (Rohlen \& LeTendre, 1995). Working to co-edit this volume I was able to interact with an international and multi-disciplinary team of scholars, and this experience has indelibly tinted my own orientation with the 
World Culture, Educational Sociology and the Impact of Information \& Communication Technology on Teachers

field of educational sociology. The issues addressed at Green Gulch were not confined to traditional sociological or even educational topics, but incorporated the questions and concerns of anthropologists, psychologists and even religious studies scholars. This multi-disciplinary approach challenged me, as a sociologist, to deal with literatures and theories that were not commonly taught in my graduate sociology seminars. I found it intellectually exciting to interact with scholars whose theories derived from bodies of knowledge created in fields such as anthropology, psychology and political science.

Since that time, I have continued to be interested in the ways that "culture" can be used to explain how schooling affects the transmission of shared values, norms and expectations. Doing graduate work at Stanford, I was deeply influenced by the neo-institutional sociology of John Meyer, Dick Scott and Francisco Ramirez. More recently described as the "world culture" school of thought, the seminal work of these and other scholars (Meyer, 2007; Meyer \& Jepperson, 2000; Meyer, Boli, Thomas, \& Ramirez, 1997; Ramirez \& Boli, 1987; Scott, 1995) has been expanded to incorporate ideas from anthropology (Anderson-Levitt, 2003) and education (Baker \& LeTendre, 2005) in order to create trans-national theories that account for the growth and spread of formal schooling around the globe (Baker, 2014). This work carries within it an emphasis on the implicit or takenfor-grantedness of many social phenomena, following a longer tradition of thinking in both the sociological (Berger, Berger, \& Kellner, 1974; Berger \& Luckman, 1966) and anthropological (Douglas, 1986) literature.

Much of the work I have done on Japan is situated in this vein of research, and has frequently had a cross-national perspective. For example, when comparing U.S. and Japanese teachers views of adolescents, I was similarly struck by these "folk theories" of learning (LeTendre, 2000) that occurred in both nations. Theoretically, the work of teachers, I argued, is conditioned by what adults (teachers and parents) generally believe about how children learn and should be taught (LeTendre, 1994; LeTendre, 1995). In other work, such as the study of adolescent patterns of socialization I did with Becky Fukuzawa (Fukuzawa \& LeTendre, 2001), we found that adolescent identity formation and socialization patterns were affected by the norms encoded in the organizational structure of Japanese junior 
high schools (middle schools). Theoretically, the work of teachers, I argued, is conditioned by what adults (teachers and parents) generally believe about how children learn and should be taught (Gerald LeTendre, 1994; LeTendre, 1995). Moreover, I argued that one reason why some educational concepts (e.g. adolescent identity crisis or hormonal disruption) did not diffuse transnationally was that they conflicted with deeply held beliefs about the nature of teaching, learning and human development. The work of teachers is not purely an outcome of the social organization of the school or of the phenomena of professionalism in latemodern capitalism (Etzioni, 1969; Lortie, 1975), but is shaped by “deeper” (e.g. implicit or taken-for-granted) assumptions about the way in which teaching and learning occurs. These "storylines" of education (LeTendre, 2000) encode alternative rationales for various educational practices, and have been explored in transnational policy contexts by some of my former students (Fraser \& Ikoma, 2015).

Over the last decade and a half, I have tried to focus more specifically on the nature of teachers' work around the world. In (LeTendre, Baker, Akiba, Goesling, $\&$ Wiseman, 2001) my colleagues and I looked at assertions that national culture (Stigler \& Hiebert, 1998) drives what teachers do, and found little support for this hypothesis in terms of the broad outlines of teachers' formal work duties. This finding stood in sharp contrast to many who have argued that a "Confucian worldview" was responsible for East Asian academic achievement (Stevenson \& Stigler, 1992; Stigler \& Hiebert, 1999). Work on trans-national reforms and policy development (LeTendre, Baker, Akiba, \& Wiseman, 2000) suggested to me that it does little good to think of national culture and trans-national forces as antipodal, but rather as part of a larger, ongoing cultural interchange. In working with colleagues to try to understand how nations can impact the quality of teaching in their nation (Akiba \& LeTendre, 2009, 2017; LeTendre \& Wiseman, 2015), I continue to consider how national or local cultures interact with trans-national or "world culture" and trans-national educational policy.

After a hiatus due to administrative duties, I returned to do field work in Japan in the fall of 2016 on a Fulbright Research Fellowship. I studied Japanese teacher attitudes toward (and uses of) information and communication technologies (ICT) in self-initiated professional development activities. I was affiliated as a visiting 
World Culture, Educational Sociology and the Impact of Information \& Communication Technology on Teachers scholar with the Institute for Comparative Culture (David Slater, Director) at Sophia University and sponsored by Dr. Akira Sakai. Using a qualitative case study approach, I worked to gain entry into schools, conducted interviews with teachers and administrators, attended professional development sessions for teachers, but also reviewed government websites and policy papers on ICT and teacher professional development in Japanese.

This work intersects with scholars from educational technology who have investigated the barriers to ICT integration in Japan (Bachnik, 2003; Fujitani, Bhattacharya, \& Akahori, 2003; Kusano et al., 2013; Nakagaki, 2015; Oshima \& Muramatsu, 2015). What was most striking about my visits to classrooms was how little had changed since my first fieldwork over 20 years before. Even in those schools with high levels of financial support, tablet-based lessons were clearly "artificially" constructed to fit into a Japanese classroom "frame." The explosive growth in access to, and use of, electronic social media and on-line learning has rapidly transformed the nature of education in many nations around the world, yet Japan has clearly lagged. In our increasingly "networked” society, schools are increasingly required to take on the duty of preparing students to manage and take advantage of diverse ICT learning opportunities. How will this play out in Japan?

Looking to the future, Japanese society faces many challenges where educational sociology can be of service. The long-term demographic shifts in population will mean an increasing reliance on smaller and smaller cohorts of younger workers; and consequently, increasing attention to educational issues and problems. New areas of interest will appear as more scholars look at the interaction of world culture and Japanese education (Kariya \& Rappleye, 2010). One example is Tsuneyoshi's (Tsuneyoshi, 2000) work on extra-curricular activities. Global trends and comparative perspectives should continue to be a mainstay for sociology of education as we attempt to understand how transnational forces are affecting Japanese education and social patterns.

I see three major areas where educational sociology will likely see the production of important and innovative studies.

The first is around issues of individual identity and schooling. In our co-edited 
volume, (Gordon, Fujita, Kariya, \& LeTendre, 2009) many scholars took up the issues of newcomers, minorities and other groups that have not been historically supported or validated in Japanese education. This turn toward more qualitative studies of how non-majority individuals and groups interact with Japanese patterns of schooling will continue to be a major source of studies. The focus on micro-social interactions and the development of more incisive techniques seems part of a larger trend in Sociology of Education as (Shimizu \& Uchida, 2009) document. At the core of these studies, I believe, is the problem of integrating concepts of individual rights and the equality of individuals that has its origins in Western contexts with the understanding of individuals within a shared Japanese identify. Increasingly, the understanding of Japanese-ness accepts a broader range of people individuals and allows variation in individual lifestyles and acceptance of individual differences. Gender will continue to be a major issue, but work on how physical or mental conditions, sexual orientation and other aspects of individual identity meet with social exclusion/inclusion (Sakai, 2015) in schools will be critical. A continued analysis of the socialization processes in schools (such as that found in Caves' book on middle schools (Cave, 2016) will be necessary to document how individuals are affected by the process of schooling. These studies will continue to add important knowledge to our understanding of Japanese schools and society in general.

A second major area of study will be social inequality, and the roles that schools play in reproducing or attenuating inequality. While this is a rather old topic in sociology of education (Rohlen, 1977), changes in the economy and policies have created conditions that augur a more divided and rigid socio-economic hierarchy. As Kariya (Kariya, 2012) and others have identified, Japan is increasingly a more stratified society, and it appears that this trend will continue in the longterm. Combined with demographic shifts, educational reform in Japan could well create stark differences in educational access and educational quality. It is likely that wide gaps in educational quality will open within the compulsory school years, undermining one of the key aspects of Japanese education that has been commented on for decades: a generally egalitarian and high quality primary education. These trends will likely be acerbated by the increasing use of, and differ- 
World Culture, Educational Sociology and the Impact of Information \& Communication Technology on Teachers

ential access to information and communication technology (ICT).

ICT integration in schools has been exceedingly slow, and at all levels Japan lags behind other nations in its adoption of educational technology in general (Bachnik, 2003). In particular, online education has been slow to spread, creating a major gap between the Japanese educational systems and those in other nations. While there is some possibility that Japanese teachers may integrate ICT more effectively in terms of specific lesson attributes, the long-term prospects are unclear. I feel that little attention has been given to the far-reaching impacts of technology on basic educational roles (structure of the university, teachers' work duties, individual learning) and the future of education. Perhaps this is because Japanese schools have been so slow to adopt educational technologies.

This is where my work (both in Japan and cross-nationally) will be focused in the coming years. How are disruptive technologies changing teacher work patterns? Will the advent of online learning and ICT in generally led to a de-professionalization of teaching as appears to be happening in other nations? Conversely, will Japanese teachers or some government sponsored coalition create an eTwinning-like (Blazic \& Verswijvel, 2017)) system for professional growth and development? To what degree will schools continue to be "bounded" from parental and community interaction?

I anticipate continuing to work with colleagues in JSET and to renew my connections with colleagues in JES. I think that further overlap of interest and methods between these groups would greatly increase the academic dynamics of Japan, and hope that events - perhaps multi-conference sponsored symposiums might focus the attention of multiple groups of scholars on the wide-ranging ramifications of ICT in education.

\section{References}

Akiba, M., \& LeTendre, G. (2009). Improving Teacher Quality: The U.S. Teaching Force in Global Context. New York: Teachers College Press.

Akiba, M., \& LeTendre, G. (Eds.). (2017). The Routledge International Handbook of Teacher Quality and Policy. New York: Routledge.

Amano, I. (1990). Education and examination in modern Japan (W. Cummings \& F. 
Cummings, Trans.). Tokyo: University of Tokyo Press.

Anderson-Levitt, K. (Ed.) (2003). Local Meanings, Global Schooling: Anthropology and World Culture Theory. New York: Palgrave Macmillan.

Bachnik, J. (Ed.) (2003). Roadblocks on the Information Highway. New York: Lexington Books.

Baker, D. (2014). The Schooled Society. Stanford, CA: Stanford University Press.

Baker, D., \& LeTendre, G. (2005). National Differences, Global Similarities: World Culture and the Future of Schooling. Stanford, CA: Stanford University Press.

Berger, P., Berger, B., \& Kellner, H. (1974). The homeless mind. New York: Random House.

Berger, P., \& Luckman, T. (1966). The social construction of reality. New York: Anchor.

Blazic, A., \& Verswijvel, B. (2017). Etwinning - A Teacher Network in Europe. In M. Akiba \& G. LeTendre (Eds.), Routledge International Handbook of Teacher Quality and Policy. New York: Routledge.

Cave, P. (2016). Schooling Selves: Autonomy, Interdependence, and Reform in Japanese Junior HIgh Education. Chicago: University of Chicago Press.

Cummings, W. (1983). Education and equality in Japan. Princeton: Princeton University Press.

Dore, R. P. (1965). Education in Tokugawa Japan. Berkeley: University of California Press.

Douglas, M. (1986). How institutions think. Syracuse, NY: Syracuse University Press.

Etzioni, A. (Ed.) (1969). The Semi-Professions and Their Organization: Teachers, Nurses, Social Workers. New York: Free Press.

Fraser, P., \& Ikoma, S. (2015). Regimes of Teacher Beliefs from a Comparative and International Perspective. In A. Wiseman \& G. LeTendre (Eds.), Promoting and Sustaining a Quality Teaching Force (pp. 111-144). Bingley, England: Emerald.

Fujitani, S., Bhattacharya, M., \& Akahori, K. (2003). ICT Implementation and Online Learning in Japan. Educational Technology, 43 ( 3 ), 33-37.

Fukuzawa, R., \& LeTendre, G. (2001). Intense Years: How Japanese Adolescents 
World Culture, Educational Sociology and the Impact of Information \& Communication Technology on Teachers

Balance School, Family and Friends. New York: RoutledgeFalmer.

Gordon, J., Fujita, H., Kariya, T., \& LeTendre, G. (Eds.). (2009). Challenges to Japanese Education: Economics, Reform and Human Rights. New York: Teachers College Press.

Ishida, H. (1993). Social mobility in contemporary Japan. London: Macmillan.

Kariya, T. (1985). The mechanism of educational selection through the hierarchical structure of high school--A study of the cooling-out process of educational aspirations. Contributions to Research in Secondary Education, 4, 11-28.

Kariya, T. (2012). Education Refrom and Social Class in Japan: The Emerging Incentive Divide. New York: Routledge.

Kariya, T., \& Rappleye, J. (2010). The Twisted, Unintended Impacts of Globalization on Japanese Education. Research in Sociology of Education, 17, 17-63.

Kusano, K., Frederiksen, S., Jones, L., Kobayashi, M., Mukoyama, Y., Yamagishi, T., ... Ishizuka, H. (2013). The Effects of ICT Environment on Teachers' Attitudes and Technology Integration in Japan and the U.S. Journal of Information Technology Education: Innovations in Practice, 12, 29-43.

LeTendre, G. (1994). Guiding them on: Teaching, hierarchy, and social organization in Japanese middle schools. Journal of Japanese Studies, 20( 1 ), 37-59.

LeTendre, G. (2000). Learning to be Adolescent: Growing up in U.S. and Japanese Middle Schools. New Haven: Yale University Press.

LeTendre, G. (Ed.) (1999). Competitor or Ally: Japan's Role in American Educational Debates. New York: Falmer.

LeTendre, G., Baker, D., Akiba, M., Goesling, B., \& Wiseman, A. (2001). Teacher's work: Institutional Isomorphism and cultural variation in the U.S., Germany and Japan. Educational Researcher, 30 ( 6 ), 3-16.

LeTendre, G., Baker, D. P., Akiba, M., \& Wiseman, A. (2000). The Policy Trap: National Educational Policy and the Third International Math and Science Study. International Journal of Educational Policy, Research and Practice, 2( 1 ), 45-64.

LeTendre, G., \& Wiseman, A. (2015). Promoting and Sustaining a Quality Teaching Workforce. Bingley, UK. : Emerald Group Publishing.

LeTendre, G. K. (1995). Disruption and reconnection: Counseling young adoles- 
cents in Japanese schools. Educational Policy, 9 ( 2 ), 169-184.

Lortie, D. C. (1975). Schoolteacher: A Sociological Study. Chicago: University of Chicago Press.

Meyer, J. (2007). Globalization: Theory and Trends. International Journal of Comparative Sociology, 48 (4), 261-273.

Meyer, J., \& Jepperson, R. (2000). The "Actors" of Modern Society: The Cultural Construction of Social Agency. Sociological Theory, 18 ( 1 ), 100-120.

Meyer, O. W., Boli, J., Thomas, G. M., \& Ramirez, F. O. (1997). World Society and the Nation-State. American Journal of Sociology, 103 (1), 144-181. doi:10.1086/231174

Nakagaki, M. (2015). Attitudes toward the use of ICT in schools in Japan. Retrieved from http://www.childresearch.net/data/school/2014_01.html

Nakane, C. (1970). Japanese society. Berkeley: University of California Press.

Oshima, K., \& Muramatsu, Y. (2015). Current Situation and Issues Related to ICT Utilization in Primary and Secondary Education. Fujitsu Science Technical Journal, 51 ( 1 ), 3-8.

Passin, H. (1965). Society and education in Japan. New York: Teachers College Press.

Ramirez, F. O., \& Boli, J. (1987). The Political Construction Of Mass Schooling: European Origins And Worldwide Institutionalization. Sociology of Education, 60 ( 1$), 2-17$.

Rohlen, T. (1977). Is Japanese education becoming less egalitarian? Journal of Japanese Studies (Winter), 37-70.

Rohlen, T., \& LeTendre, G. (1995). Teaching and learning in Japan. New York: Cambridge University Press.

Rohlen, T. P. (1983). Japan's high schools. Berkeley: University of California Press.

Sakai, A. (2015). Social Exclusion and Social Inclusion in Education. The Journal of Educational Sociology, 96, 5-24.

Schoppa, L. (1991). Education reform in Japan: A case of immobilist policies. New York: Routledge.

Scott, R. (1995). Institutions and Organizations. Thousand Oaks, CA: Sage Publication. 
World Culture, Educational Sociology and the Impact of Information \& Communication Technology on Teachers

Shimahara, N. (1978). Socialisaton for college entrance examinations in Japan. Comparative Education, 14 ( 3 (October)), 253-266.

Shimahara, N. (1979). Adaptation and Education in Japan. New York: Praeger.

Shimizu, M., \& Uchida, R. (2009). Qualitative Researches in the Last Decade: Review of the Journal of Educational Sociology. Journal of Educational Sociology, 103-121.

Stevenson, H., \& Stigler, J. (1992). The learning gap. New York: Summit Books.

Stigler, J., \& Hiebert, J. (1998). Teaching is a Cultural Activity. American Educator (Winter), 4-11.

Stigler, J., \& Hiebert, J. (1999). The Teaching Gap: best ideas from the world's teachers for improving education in the classroom. New York: Free Press.

Thurston, D. (1973). Teachers and politics in Japan. Princeton: Princeton University Press.

Tsuneyoshi, R. (2000). The Japanese Model of Schooling: Comparisons with the United States: Routledge.

Vogel, E. (1979). Japan as Number One: Lessons for America. Cambridge, MA: Harvard University Press.

White, M. (1987). The Japanese Educational Challenge. New York: Kodansha. 